\title{
ANALISIS YURIDIS EKSISTENSI PEJABAT PEMBUAT AKTA TANAH (PPAT) DALAM PERSPEKTIF PENDAFTARAN TANAH DI KECAMATAN TANJUNGPINANG TIMUR (STUDI PENELITIAN DIKANTOR NOTARIS DAN PEJABAT PEMBUAT AKTA TANAH AFIKA HERSANY)
}

\author{
Della Monika \\ Program Magister Kenotariatan Universitas Batam \\ Jalan Uniba No.5 Batam, Kepulauan Riau \\ Email : della.monika95@gmail.com
}

\begin{abstract}
This study aims to determine the implementation of land registration in order to guarantee and provide legal certainty to landowners, so that it can be legally accountable, especially at the time of registration documents in the process of issuing certificates. Related to this, people who conducted the land registration to be more know about land sector and find out the supporting and inhibiting factors that implemented during land registration in East Tanjungpinang District. The results showed that the juridical analysis of the existence the Land Deed Officer (PPAT) in the land registration perspective in East Tanjungpinang District had been well implemented, this was indicated by the implementation of land registration activities in the Notary Office and Land Deed Officer Afika Hersany SH, MKn and at the Office of the National Land Agency (BPN) of Tanjungpinang City which is generally has been implemented in accordance with the correct procedures in its implementation.
\end{abstract}

Keyword; Juridical Analysis, Land Registration, Legal Certainty.

\begin{abstract}
Abstrak
Penelitian ini bertujuan untuk mengetahui pelaksanaan pendaftaran tanah guna untuk menjamin dan memberikan kepastian hukum terhadap pemilik tanah, sehingga dapat dipertanggung jawabkan secara hukum terutama sekali pada saat pendaftaran aktanya dalam proses penerbitan sertifikat. Terkait dengan hal ini, masyarakat yang melakukan pendaftaran tanah agar lebih mengetahui dibidang pertanahan serta untuk mengetahui faktor-faktor pendukung dan penghambat dalam pelaksanaan pendaftaran tanah di Kecamatan Tanjungpinang Timur. Hasil penelitian menunjukkan bahwa analisis yuridis eksistensi Pejabat Pembuat Akta Tanah (PPAT) dalam perspektif pendaftaran tanah di Kecamatan Tanjungpinang Timur telah terlaksana dengan baik hal ini ditandai dengan pelaksanaan kegiatan pendaftaran tanah di Kantor Notaris dan Pejabat Pembuat Akta Tanah (PPAT) Afika Hersany S.H.,M.K.n dan di Kantor Badan Pertanahan Nasional (BPN) Kota Tanjungpinang yang pada umumnya telah dilaksanakan sesuai dengan prosedur sesuai dengan pelaksanaannya.
\end{abstract}

Kata Kunci; Analisis Yuridis, Pendaftaran Tanah, Kepastian Hukum. 


\section{PENDAHULUAN}

Penyelenggaraan pendaftaran tanah dalam masyarakat merupakan tugas negara. Sebagai bagian yang sangat penting di kehidupan manusia, pengaturan tentang tanah diatur secara tegas dalam peraturan perundang-undangan. ${ }^{1}$ Penguasaan dan penggunaan tanah tidak dapat dilakukan dengan begitu saja, tetapi ada campur tangan pemerintah dalam hal ini. Sebagaimana yang tercantum dalam Pasal 33 ayat (3) Undang-Undang Dasar Negara Republik Indonesia Tahun 1945, yang menegaskan bahwa "bumi, air dan kekayaan alam yang terkandung didalamya dikuasai oleh negara dan dipergunakan sebesar-besarnya untuk kemakmuran rakyat". Dapat diartikan dalam ayat ini bahwa negara wajib menguasai bumi, air dan ruang angkasa serta kekayaan alam yang terkandung di dalamnya untuk mewujudkan kesejahteraan seluruh rakyat Indonesia.

Kepastian hukum juga penting untuk mengatur hidup masyarakat adil, agar terhindar dari pelanggaran yang dapat dilakukan oleh masyarakat ataupun penegak hukum itu sendiri. Untuk itu maka dalam pelaksanaannya dapat memedomani dan berlandaskan kepada tiga pilar dan/atau jangkar utama yang sangat fundamental diantaranya harus berlandaskan kepada seluruh nilai-nilai Pancasila sebagai Dasar Negara, pandangan hidup, jiwa dan kepribadian bagi seluruh rakyat dan bangsa Indonesia; harus berlandaskan amanat dan ketentuan sebagaimana yang telah diamanatkan didalam Konstitusi Negara yaitu Undang-Undang Dasar Negara Republik Indonesia Tahun 1945; dan harus pula berlandaskan kepada suatu asas bahwa Indonesia adalah negara hukum. ${ }^{2}$

Di dalam prakteknya, masyarakat dalam melakukan pengurusan pendaftaran tanah ada yang dapat mengurus sendiri dan ada juga memerlukan jasa dari PPAT. Dalam bukunya Habib Adjie disebutkan bahwa jabatan PPAT dan akta PPAT belum mempunyai kedudukan yang kuat, oleh karena itu agar kedudukan hukumnya kuat maka harus diatur dan dibuatkan Undang-Undang Jabatan Pembuat Akta Tanah. ${ }^{3}$

\footnotetext{
${ }^{1}$ Idham, Analisis Kritis Pendaftaran Tanah Hak Ulayat Milik Masyarakat Adat Untuk Meneguhkan Kepastian Hukum dan Peningkatan Ekonomi Kerakyatan, Penerbit PT Alumni, Bandung, 2014, hal 103.

2 Idham, Paradigma Politik Hukum Pendaftaran Tanah dan Konsolidasi Tanah dalam Perspektif Free Trade Zone (FTZ) di Kota Batam, Penerbit Alumni, Bandung, 2016, hal 2.

${ }^{3}$ Habib Adjie, Meneropong Khazanah Notaris dan PPAT di Indonesia (Kumpulan Tulisan tentang Notaris dan PPAT), Citra Aditya Bakti, Bandung, 2009, hal. 267-275.
} 
Pejabat Pembuat Akta Tanah pada pelaksanaan pendaftaran tanah, berfungsi sebagai perpanjangan tangan pemerintah dalam melaksanakan tujuan pendaftaran tanah. Akta-akta yang dibuat oleh Pejabat Pembuat Akta Tanah (PPAT) sebagai Pejabat Umum tersebut harus dapat dipertanggung jawabkan secara hukum, terutama sekali pada saat pendaftaran aktanya dalam proses penertiban sertifikat. Pasal 1 angka 24 PP No.24 Tahun 1997 menyatakan bahwa, "Pejabat Pembuat Akta Tanah adalah pejabat umum yang diberi kewenangan untuk membuat akta-akta tertentu."

Profesionalitas Pejabat Pembuat Akta Tanah (PPAT) dalam pembuatan akta perlu ditingkatkan. Salah satu cara Pejabat Pembuat Akta Tanah (PPAT) meningkatkan profesionalitasnya adalah dengan memahami secara keseluruhan perangkat hukum dibidang pertanahan, sehingga dalam pelaksanaannya tidak dihadapkan pada permasalahan, karena adanya perbedaan persepsi terhadap ketentuan yang ada. ${ }^{4}$

Semakin meningkatnya kebutuhan perkembangan tanah tersebut mengharuskan seluruh Rakyat Indonesia harus mampu memanfaatkan dan menggunakan sumber daya tanah secara baik dan benar, sesuai dengan peraturan yang berlaku, agar memperoleh manfaat yang sebesar-besarnya bagi kemakmuran dan kesejahteraan manusia. Berkaitan dengan hal tersebut diatas dijelaskan dalam Pasal 1 ayat (2) Undang-Undang Nomor 5 Tahun 1960 Tentang Peraturan Dasar Pokok-Pokok Agraria. Menentukan dan mengatur hubungan hukum dengan memberikan berbagai macam hak atas tanah baik kepada individu maupun badan hukum, selain memberikan wewenang untuk memanfaatkan tanah tersebut sesuai dengan hak yang dipegangnya dan sepanjang tidak bertentangan dengan hukum yang berlaku, juga mengharuskan kepada pemegang hak tersebut untuk mendaftarkan hak atas tanahnya yang bertujuan untuk mendapatkan kepastian hukum. ${ }^{5}$

Adapun tujuan dari pendaftaran tanah menurut PP No.24 Tahun 1997 yaitu untuk memberikan kepastian hukum dan perlindungan hukum kepada pemegang hak atas suatu bidang tanah, satuan rumah susun dan hak-hak lain yang terdaftar

\footnotetext{
${ }^{4}$ Soedharyo Soimin, Status Hak dan Pembebasan Tanah, Edisi Kedua, Sinar Grafik, Jakarta, 2004 , hal. 159.
}

5 Effendi Bahtiar, Kumpulan Tulisan Tentang Hukum Tanah, Alumni, Bandung, 1993, hal. 5. 
agar dengan mudah dapat membuktikan dirinya sebagai pemegang hak yang bersangkutan.

Dalam pendaftaran tanah dapat menyesuaikan data fisik dan data yuridis dalam peta pendaftaran tanah dan perubahan-perubahan yang terjadi kemudian. ${ }^{6}$ PPAT wajib mengedukasi hukum dengan benar hal ini berguna untuk perlindungan hukum bagi semua pihak guna meminimalisir sengketa dikemudian hari dan dilihat pada penentuan harga bahwa juga terdapat perbedaan pada NJOP dan praktiknya. Melihat dari keberadaan Pejabat Pembuat Akta Tanah (PPAT) yang semakin meningkat, maka diperlukan ilmu yang secara mendalam mengenai perspektif pendaftaran serta perlindungan hukumnya agar dapat diketahui oleh masyarakat.

Oleh sebab itu peranan PPAT didalam pembuatan akta tanah dan pendaftaran tanah sangat penting untuk perlindungan hukum semua pihak.Aturan mengenai wewenang PPAT dan peran PPAT dalam pembuatan akta tanah harus berjalan sesuai dengan aturan hukum yang ada.

Dari uraian latar belakang tersebut diatas penulis merasa tertarik dan perlu membahas permasalahan yang ada dengan mengambil judul Analisis Yuridis Eksistensi Pejabat Pembuat Akta Tanah (PPAT) dalam Perspektif Pendaftaran Tanah di Kecamatan Tanjungpinang Timur (Studi Penelitian di Kantor Notaris Afika Hersany).

Berdasarkan uraian pada latar belakang yang dikemukakan diatas, permasalahan dalam penelitian yang akan dibahas dalam penyusunan jurnal ini dapat dirumuskan sebagai berikut:

1. Bagaimana Pengaturan Hukum Peranan Pejabat Pembuat Akta Tanah (PPAT) dalam persektif pendaftaran tanah?

2. Bagaimana Implementasi Peranan Pejabat Pembuat Akta Tanah (PPAT) dalam perspektif pendaftaran tanah di Kecamatan Tanjungpinang Timur?

3. Apa saja yang menjadi Faktor Kendala mengenai Peranan Pejabat Pembuat Akta Tanah dalam perspektif pendaftaran tanah di Kecamatan Tanjungpinang Timur?

${ }^{6}$ Lihat Pasal 1868 Kitab Undang-Undang Hukum Perdata, Pasal 165 Herziene Indonesisch Reglemen, dan Pasal 285 Rechtsreglement Buitengewesten bahwa Perbedaan Pokok antara akta otentikdengan akta dibawah tangan adalah cara pembuatan atau terjadinya akta tersebut. Suatu akta otentik adalah suatu akta yang dibuat dalam bentuk yang ditentukan Undang-Undang oleh atau dihadapan Pejabat Umum yang berwenang untuk itu (Seperti Notaris, Hakim, Panitera, Juru Sita, Pegawai Pencatat Sipil) ditempat akta itu dibuat. 
Metode Penelitian menjelaskan seluruh rangkaian kegiatan yang akan dilakukan dalam rangka menjawab pokok permasalahan atau untuk membuktikan asumsi yang dikemukakan. Metode penelitin merupakan cara yang diterapkan oleh peneliti dalam penelitian yang dilakukannya.

Pada penelitian ini menurut jenis, sifat dan tujuan spesifikasi penelitian hukum oleh Soerjono Soekanto merupakan jenis penelitian hukum normatif empiris atau sosiologis atau disebut juga applied law research, ${ }^{7}$ yaitu penelitian hukum mengenai pemberlakuan atau implementasi ketentuan hukum normatif (kodifikasi, UndangUndang atau kontrak) secara in action pada setiap peristiwa hukum tertentu yang terjadi dalam masyarakat.

Penelitian hukum ini didukung dengan data primer, yaitu data yang didapatkan dengan melakukan wawancara langsung secara mendalam (deep interview) dititik lokasi penelitian dengan pihak yang terkait dengan permasalahan yang diangkat dalam penulisan ini. ${ }^{8}$

Data sekunder yaitu data yang telah dikumpulkan untuk maksud selesai menyelesaikan masalah yang sedang dihadapi. Data ini dapat ditemukan dengan cepat. Data sekunder merupakan data yang telah tersedia. ${ }^{9}$ Didalam penelitian hukum, data sekunder mencakup: ${ }^{10}$ Bahan hukum primer, yaitu bahan-bahan hukum yang mengikat dan terdiri dari norma (dasar) atau kaidah dasar, peraturan dasar, peraturan perundang-undangan, bahan hukum yang tidak dikodifikasikan, yurisprudensi, traktat dan bahan hukum dari zaman penjajahan yang hingga kini masih berlaku. Bahan hukum sekunder, yang memberikan penjelasan mengenai bahan hukum primer, seperti rancangan undang-undang, hasil-hasil penelitian, hasil karya dari kalangan hukum, dan seterusnya. Bahan hukum tertier, yakni bahan yang memberikan petunjuk maupun penjelasan terhadap bahan hukum primear dan sekunder, contohnya adalah kamus, ensiklopedia, indeks kumulatif, dan seterusnya.

7 Salim HS dan Erlies Septiana Nurbani, Penerapan Teori Hukum Pada Tesis dan Disertasi, Raja Grafindo Persada, Jakarta, 2014, hal.11.

8 Idham, Op.cit, hal. 12.

9 Zainudin Ali, 2009, Metode Penelitian Hukum, Sinar Grafka, Jakarta Ibid, hlm.53

10 Soerjono Soekanto dan Sri Mamudji, 2010, Penelitian Hukum Normatif, PT. Raja Grafindo Persada, Jakarta, hlm.13 


\section{PEMBAHASAN}

Setelah semua data yang dibutuhkan terkumpul maka peneliti akan melakukan analisa terhadap data yang tersebut. Selanjutnya data tersebut disajikan dibahas dengan cara menghubungkan data sesuai dengan kajian yuridis normatif, pendapat para ahli serta peraturan perundang-undangan yang berlaku.

\subsection{Pengaturan Hukum Peranan Pejabat Pembuat Akta Tanah dalam Perspektif Pendaftaran Tanah}

Pejabat Pembuat Akta Tanah (PPAT) menurut pasal 1 ayat (1) PP omor 37 tahun 1998 adalah Pejabat Umum yang diberi kewenangan untuk membuat akta-akta otentik mengenai perbuatan hukum tertentu mengenai Hak Atas Tanah atau Hak Milik atas Satuan Rumah Susun. ${ }^{11}$ Dalam PP Nomor 37 Tahun 1988 ini juga memuat PPAT sementara dan PPAT Khusus. PPAT sementara adalah pejabat pemerintah yang ditunjuk karena jabatannya.

Untuk melaksanakan tugas PPAT dan membuat akta didaerah yang belum cukup PPAT dalam hal ini yang ditunjuk adalah camat. PPAT khusus adalah Pejabat Badan Pertanahan Nasional yang ditunjuk karena jabatannya untuk melaksanakan tugas PPAT dengan membuat akta PPAT tertentu, khusus dalam rangka pelaksanaan program atau tugas pemerintah tertentu.

Dari ketentuan pasal 1 dan pasal 3 PP nomor 37 tahun 1998 dapat disimpulkan bahwa akta-akta yang dibuat oleh PPAT adalah Akta Otentik oleh karena itu PPAT dalam membuat akta harus mendasarkan pada syarat-syarat dan prosedur yang ditentukan oleh peraturan perundang-undangan agar memenuhi syarat sebagai sebagai akta otentik. Pengertian otentik dijelaskan oleh pasal 1868 KUHPerdata yang disebutkan "suatu akta otentik ialah suatu akta yanag didalam bentuk yang ditentukan oleh undang-undang dibuat oleh atau dihadapan pegawai-pegawai umum yang berkuasa untuk itu di tempat dimana akta dibuatnya."12 Pengertian otentik untuk akta PPAT tentulah harus mencakup pada pengertian:

\footnotetext{
11 Mustofa, Tuntunan Pembuatan Akta-Akta PPAT, Penerbit Karya Media, Yogyakarta, 2014, hal 1-2

$12 \mathrm{Ibid}$, hal. 8. Semua akta yang merupakan kewenangan PPAT untuk membuatnya adalah akta yang bersifat otentik, oleh karena itu PPAT dalam membuat akta harus berhati-hati dalam semua aspek termasuk bagaimana cara membuat akta yang benar sehingga memenuhi syarat untuk menjadi akta otentik. Isi yang dituangkan dalam akta juga harus apa adanya jangan berisi hal-hal yang direkayasa karena dapat menimbulkan masalah dikemudian hari.
} 
1. Dibuat dalam bentuk yang ditentukan oleh undang-undang

2. Dibuat dihadapan pegawai umum yaitu dihadapan PPAT

3. Dibuat dan diselesaikan dalam daerah kerja PPAT

4. Untuk tanah-tanah atau Hak Mili atas Satuan Rumah Susun yang berada/terletak dalam daerah kerja PPAT.

Kedudukan Pejabat Pembuat Akta Tanah (PPAT) sebagai pejabat umum yang membantu Kepala Kantor Pertanahan dalam pelaksanaan sebagian kegiatan pendaftaran tanah dengan kewenangan membuat 8 akta. Fungsi dan tanggung jawab Pejabat Pembuat Akta Tanah (PPAT) diantaranya membuat akta sebagai bukti telah dilakukannya perbuatan hukum tertentu mengenai hak atas tanah atau hak milik atas satuan rumah susun. Kemudian menjadi dasar bagi pendaftaran perubahan data pendaftaran tanah yang diakibatkan oleh perbuatan hukum itu. Akta PPAT wajib dibuat sesuai dengan Perkaban Nomor 8 Tahun 2012, sehingga dapat dijadikan dasar yang kuat untuk pendaftaran pemindahan hak atas tanah dan pembebanan hak yang bersangkutan. Dan menyampaikan akta PPAT dan dokumen pendukung akta kepada kepala kantor pertanahan dalam waktu 7 hari kerja. ${ }^{13}$

Pokok Pejabat Pembuat Akta Tanah (PPAT) berwenang membuat akta otentik mengenai perbuatan hukum yang merupakan tugas pokoknya. ${ }^{14}$ Tugas Pokok Pokok Pejabat Pembuat Akta Tanah (PPAT) diatur dalam pasal 2 PP Nomor 37 tahun 1998, yaitu melaksanakan sebagian kegiatan Pendaftaran Tanah dengan membuat akta sebagai bukti telah dilakukannya perbuatan hukum tertentu mengenai Hak Atas Tanah atau Hak Milik atas Satuan Rumah Susun yang akan dijadikan dasar bagi pendaftaran perubahan data pendaftaran tanah yang akan diakibatkan oleh perbuatan hukum itu. Perbuatan hukum yang dimaksud adalah: Jual Beli, Tukar Menukar, Hibah, Pemasukan ke dalam Perusahaan (inbreng), Pembagian Hak Bersama, Pemberian Hak Guna Bangunan/Hak Pakai atas Tanah Hak Milik,

13 Udin Narsudin, Buku Pembekalan PPAT, Penerbit Pengurus Pusat Ikatan Pejabat Peembuat Akta Tanah, 2015, hal. 33.

14 Effendi Perangin, Hukum Agraria di Indonesia, Raja Grafindo Persada, Jakarta, 1994, hal. 3. Untuk melaksanakan tugas pokok tersebut diatas seorang PPAT mempunyai kewenangan membuat akta otentik mengenai segala perbuatan hukum yang telah ditentukan oleh peraturan perundang-undangan yang berlaku bagi jabatannya. PPAT hanya berwenang membuat akta mengenai perbuatan hukum yang disebut secara khusus dalam penunjukannya. 
Pemberian Hak Tanggungan, dan Pemberian Kuasa Membebankan Hak Tanggungan. 15

Untuk melaksanakan tugas pokok tersebut maka oleh pasal 3 PP Nomor 37 tahun 1998, Pejabat Pembuat Akta Tanah diberi kewenangan untuk membuat Akta Otentik atas 8 (delapan) macam perbuatan hukum yang dimaksud diatas. Dengan demikian dapat disimpulkan bahwa Pejabat Pembuat Akta Tanah hanya mempunyai kewenangan untuk membuat 8 (delapan) macam akta tersebut diatas, diluar 8 (delapan) macam akta itu PPAT tidak berwenang untuk membuatnya sehingga tidak mungkin PPAT diminta untuk membuat akta diluar 8 (delapan) macam akta tersebut. 16

Pengertian pendaftaran tanah menurut Pasal 1 Peraturan Pemerintah (PP) Nomor 24 Tahun 1997 tentang Pendaftaran Tanah adalah rangkaian kegiatan yang dilakukan oleh pemerintah secara terus menerus berkesinambungan dan teratur meliputi pengumpulan, pengelolaan, pembukuan dan penyajian serta pemeliharaan data fisik dan yuridis, dalam bentuk peta dan daftar mengenai bidang-bidang tanah dan satuan-satuan rumah susun termaksud pemberian sertifikat, sebagai surat tanda bukti hanya bidang-bidang tanah yang sudah ada haknya dan hak milik atas satuan rumah susun termasuk pemberian sertifikat sebagai surat tanda bukti haknya bagi bidang-bidang tanah yang sudah ada haknya dan hak milik atas satuan rumah susun serta hak-hak tertentu yang membebaninya. ${ }^{17}$

Tujuan pendaftaran $\operatorname{tanah}^{18}$ diatur dalam Pasal 19 Undang-Undang Pokok Agraria yaitu bahwa pendaftaran tanah diselenggarakan dalam rangka menjamin kepastian hukum di bidang pertanahan, sebagaimana pada garis besarnya telah

15 A.P.Parlindungan, Pedoman Pelaksanaan Undang-Undang Pokok Agraria dan Tata Cara Pejabat Pembuat Akta Tanah, CV. Mandar Maju, Bandung, 1991, hal.180. Dijelaskan bahwa kejelasan itu itu sangat diperlukan untuk memberikan beberapa kepastian hukum, dengan melihat pada pasal 50 ayat (2) Undang-Undang Pokok Agraria dipandang perlu lebih lanjut mengenai Hak Guna Usaha, Hak Guna Bangunan dan Hak Pakai untuk melengkapi ketentuan yang sudah ada didalam Undang-Undang Pokok Agraria.

${ }_{16}$ Mustofa, Op.cit, hal 2.

17 Boedi Harsono,. Hukum Agraria Indonesia: Sejarah Pembentukan UUPA Isi dan Pelaksanaanya

Ed. Revisi. Cet.8. Djambatan, 2003. Jakarta, hal. 72.

18 Bernhard Limbong, Konflik Pertanahan, Margaretha Pustaka, Jakarta, 2012, hal 81. Sesuai dengan ketentuan Pasal 19 Undang-Undang Republik Indonesia Nomor 5 Tahun 1960 Tentang Peraturan Dasar PokokPokok Agraria bahwa: Untuk Menjamin kepastian hukum oleh Pemerintah diadakan pendaftaran tanah diseluruh wilayah Republik Indonesia menurut ketentuan yang diatur dengan Peraturan Pemerintah, tujuan pendaftaran tanah ialah dalam rangkan menjamin kepastian hukum dibidang pertanahan (rechtkadaster atau legal cadaster). Dengan memiliki sertifikat, maka kepastian hukum berkenaan dengan jenis hak atas tanah, subyek hak, dan obyek haknya menjadi nyata. 
dikemukakan dalam pendahuluan tujuan pendaftaran tanah seperti yang dinyatakan

dalam Pasal 3 Peraturan Pemerintah Nomor 24 Tahun 1997 adalah:

1. Untuk memberikan kepastian hukum dan perlindungan hukum kepada

pemegang hak atas suatu bidang tanah satuan rumah susun dan hak-hak lain yang terdaftar agar dengan mudah dapat membuktikan dirinya sebagai pemegang hak yang bersangkutan.

2. Untuk menyediakan informasi kepada pihak-pihak yang berkepentingan termaksud pemerintah agar dengan mudah, dapat memperoleh data yang diperlukan dalam mengadakan perbuatan hukum mengenai bidang-bidang tanah dan satuan-satuan rumah susun yang sudah terdaftar.

3. Untuk terselenggarakan tertib administrasi pertanahan. Terselenggaranya pendaftaran tanah secara baik merupakan dasar dan perwujudan, tertib administrasi di bidang pertanahan untuk mencapai tertib administrasi tersebut disetiap bidang tanah dan satuan rumah susun termaksud peralihan, pembebanan dan hapusnya wajib didaftarkan.

Dalam rangka pendaftaran tanah ${ }^{19}$, Pemerintah menentukan pejabat secara khusus yang diberikan kewenangan membuat akta otentik. Irwan Soerdjo mengemukakan bahwa ada 3 (tiga) unsur esensial agar terpenuhinya syarat formal suatu akta otentik, yaitu pertama di dalam bentuk yang ditentukan oleh undangundang. Kedua dibuat oleh dan di hadapan Pejabat Umum. Dan ketiga akta yang

19 Darwin Ginting, Hukum Kepemilikan Hak Atas Tanah Bidang Agraria Bisnis Hak Menguasai Negara dalam Sistem Hukum Pertanahan Indonesia, Penerbit Ghalia Indonesia, Jakarta, 2015, hal 193. Pembangunan dan penguasaan tanah harus merupakan pembagunan berkelanjutan yang berwawasan lingkungan hidup, yaitu pembangunan secara sadar dan terencana, yang memadukan lingkungan hidup, termasuk sumber daya kedalam proses pembangunan untuk menjamin kemampuan, kesejahteraan, dan mutu hidup generasi masa kini dan generasi masa depan. Agar pembangunan dan penguasaan tanah sebagai sumber daya alam sesuai dengan program-program pembangunan berbasiskan kerakyatan sebagaimana diamanahkan dalam Pancasila dan Undang-Undang Negara Republik Indonesia Tahun 1945, maka perlu diselenggarakan pembangunan tanah yang tidak dapat dilepaskan dari pengaturan, penguasaan, dan pemilikan tanah. Pada tanggal 24 September 1960, Undang-Undang Nomor 5 Tahun 1960 tentang Peraturan Dasar Pokok-Pokok Hukum Agraria disahkan sebagai Undang-Undang. Undang-Undang Nomor 5 Tahun 1960 tentang Peraturan Dasar Pokok-Pokok Hukum Agraria. Hal itu merupakan sejarah baru dan suasana baru bagi rakyat Indonesia untuk dapat menikmati sepenuhnya bumi, air, ruang angkasa dan kekayaan alam di bumi Indonesia ini, teruama kaum tani yang selama ini menanam tanaman di atas tanahnya sendiri. Perombakan hukum agraria kolonial itu dimaksudkan untuk merubah hukum kolonial menjadi hukum nasional. Selain itu perubahan tersebut bertugas untuk menghilangkan dualisme hukum yang berlaku serta memberikan kepastian hukum atas hak-hak seseorang atas tanah. Sehubungan dengan kepastian hukum, perlu dikemukakan bahwa dalam hal tersebut pada umumnya terkait dengan hukum tertulis. Namun demikian, hukum tertulis bukanlah satu-satunya sumber hukum. Kepastian hukum perlu diselaraskan dengan tujuan hukum lainnya, antara lain keadilan dan kemanfaatan. Dengan demikian, dalam penerapan hukum tertulis juga perlu diperhatikan hukum yang hidup dan berkembang dalam masyarakat (living law). 
dibuat oleh atau di hadapan Pejabat Umum yang berwenang untuk itu dan di tempat dimana akta itu dibuat. ${ }^{20}$

\subsection{Implementasi Peranan Pejabat Pembuat Akta Tanah (PPAT) dalam Perspektif Pendaftaran Tanah}

Secara ideal pendaftaran tanah harus menjangkau seluruh wilayah daratan di Indonesia. Apabila seluruh tanah terdaftar, maka kecil kemunginan terjadinya konflik sengketa pertanahan. Batas negara termasuk tanah kawasan hutan dan tanah milik akan menjadi jelas sehingga sengketa batas dapat dihindari sedini mungkin, agar teciptanya kepastian hukum dan perlindungan hukum kepada pemegang hak atas suatu bidang tanah, dan hak-hak lain yang terdaftar. ${ }^{21}$

Pada proses pendaftaran tanah dapat dilakukan sendiri atau melalui Pejabat Pembuat Akta Tanah. Namun kenyataannya proses pendaftaran tanah biasanya lebih banyak menggunakan jasa Pejabat Pembuat Akta Tanah, karena adanya kebutuhan atas akta Pejabat Pembuat Akta Tanah. Apabila melakukan pendaftaran tanah melalui Pejabat Pembuat Akta Tanah para pihak pemohon pendaftaran tanah akan lebih dimudahkan dalam mengurusnya, karena semua hal transaksi pensertifikatan tanah akan dikerjakan oleh Pejabat Pembuat Akta Tanah. Sehingga para pihak tidak perlu lagi untuk kesana-kemari mengurus segala hal terkait pendaftaran tanah. Namun, apabila melakukan pendaftaran tanah melalui Pejabat Pembuat Akta Tanah maka dalam urusan pendaftaran tanah pada Kantor Pertanahan akan dikenakan biaya tambahan yang ditarik tanpa kuitansi, yang sering disebut dengan "biaya lainlain".

Dalam rangka peranan Pejabat Pembuat Akta Tanah (PPAT) dalam proses pendaftaran tanah, maka adanya pihak-pihak yang berkepentingan dalam pendaftaran tanah diantaranya:

20 Irwan Soerodjo, Kepastian Hukum Hak Atas Tanah di Indonesia, Arkola, Surabaya, 2003, hal 148.

21 Waskito dan Hadi Arnowo, Pertanahan Agraria dan Tata Ruang, Penerbit Prenadamedia Group, Jakarta, 2018, hal. 102-13. Dalam implementasi terkait dengan proses pendaftaran tanah maka dilakasanakan dengan asas sederhana, aman, terjangkau, mutakhir, dan terbuka. Asas tersebut merupakan implementasi dari kehendak Pasal 19 UUPA, yaitu menyelenggarakan pendaftaran tanah sesuai kemampuan negara dan masyarakat, keperluan lalu lintas ekonomi serta kemungkinan penyelenggaraannya, menurut pertimbangan Menteri Agraria. Perkembangan teknologi juga menjadi pertimbangan penyelenggaraan pendaftaran tanah dalam hal pembuatan peta dasar. Adapun untuk objek pendaftaran tanah, dapat meluas keruang bawah tanah, ruang atas tanah dan ruang diatas permukaan air. 
a. Pemilik tanah artinya dengan caranya kepada pemilik tanah diberikan tanda bukti sertifikat sehingga pemilik dengan mudah membuktikan hak atas tanahnya, karna membuktikan hak atas tanah tidak harus dengan sertifikat, petuk pajak, saksi-saksi jika terjadi gugatan pemilik tanah bisa langsung membuktikan kepemilikan tanah tersebut dengan menunjukkan sertifikat.

b. Bagi pihak ketiga yang berkepentingan atas tanah itu bisa pembeli/kreditur artinya pihak ketiga bisa mengecek data yang ada dikantor pertanahan atau dengan mudah memperoleh keterangan yang dapat dipercaya degan memanfaatkan asas publisitas yaitu kantor pertanahan terbuka untuk umum.

c. Bagi Negara artinya untuk perencanaan pembangunan dan pengawasan pendaftaran tanah. ${ }^{22}$

Agar menjamin kepastian hukum oleh pemerintah diadakan pendaftaran tanah diseluruh wilayah Republik Indonesia (Pasal 19 ayat 1 PP 24 tahun 1997) yang meliputi perlunya pengukuran, perpetaan dan pembukuan tanah. Kemudian pendaftaran hak-hak atas tanah dan perlihan hak-hak tersebut. Dan terakhir adanya pemberian surat-surat tanda bukti hak, yang berlaku sebagai alat bukti yang kuat (Pasal 19 ayat 2).23

Dalam praktek sehari-hari Kantor PPAT tidak hanya melakukan kegiatankegiatan yang bersumber dari pembuatan 8 (delapan) macam kata yang merupakan kewenangan Pejabat Pembuat Akta Tanah, namun seringkali kantor PPAT mengurus hal-hal yang tidak ada hubungannya dengan kewenangan Pejabat Pembuat Akta Tanah yaitu hal-hal yang timbul atas permintaan dari masyarakat, yang menyebabkan kantor Pejabat Pembuat Akta Tanah membantu untuk menyelesaikannya. Jadi hanya semacam bantuan Pejabat Pembuat Akta Tanah untuk membantu kepentingan masyarakat karena masyarakat tidak biasa atau tidak sempat untuk mengurusnya.

Kewenangan Pejabat Pembuat Akta Tanah untuk membuat akta didasarkan pada kenyataan dimana tanah atau Hak Milik atas Satuan Rumah Susun tersebut terletak/berada, bukan pada hal dimanakah para penghadap (misalnya penjual dan pembeli) dapat berkumpul, atau pada hal dimanakah domisili pemegang hak atau

\footnotetext{
22 Idham, Op.cit, hal. 1. Memerhatikan terhadapa beberapa variabel yang terkandung, maka dalam bagian ini disajikan analisis bahwa keberadaan suatu hak atas tanah, peran Negara sangat diperlukan dalam hal ini.

23 Peraturan Pemerintah Nomor 24 Tahun 1997 tentang Pendaftaran Tanah.
} 
domisili calon penerima hak berada. Kewenangan Notaris untuk membuat akta didasarkan pada kehadiran (para) penghadap dikantor Notaris, selama (para) penghadap dapat datang ke kantor Pejabat Pembuat Akta Tanah maka Pejabat Pembuat Akta Tanah berwenang untuk membuatkan aktanya tanpa harus melihat obyek perjanjian ada dimana, jadi yang dipentingkan adalah (para) penghadap dapat datang dan menandatangani akta di kantor Pejabat Pembuat Akta Tanah. ${ }^{24}$ surat ukur disimpan di Badan Pertanahan Nasional.

Sistem pendaftaran tanah yang dianut Undang-Undang Pokok Agraria adalah sistem pendaftran hak (registration of titles), buktinya adalah nampak dengan adanya buku tanah sebagai dokumen yang memuat data yuridis dan data fisik yang dihimpun dan disajikan serta diterbitkan sertifikat sebagai surat tanda bukti hak yang didaftar. Hal-hal yang harus diperhatikan sebelum membuat akta Pejabat Pembuat Akta Tanah melihat berdasarkan Pasal 39 Peraturan Pemerintah Nomor 24 tahun 1997, Pejabat Pembuat Akta Tanah menolak untuk membuat akta jika: Mengenai bidang tanah yang sudah terdaftar atau hak milik atas satuan rumah susun, kepadanya tidak disampaikan sertipikat asli hak yang bersangkutan atau sertipikat yang diserahkan tidak sesuai dengan daftar-daftar yang ada di Kantor Pertanahan; atau 25 Mengenai bidang tanah yang belum terdaftar, kepadanya tidak disampaikan: surat bukti hak sebagaimana dimaksud dalam Pasal 24 ayat (1) atau surat keterangan Kepala Desa/Kelurahan yang menyatakan bahwa yang bersangkutan menguasai bidang tanah tersebut sebagaimana dimaksud dalam Pasal 24 ayat (2); dan surat keterangan yang menyatakan bahwa bidang tanah yang bersangkutan belum bersertipikat dari Kantor Pertanahan, atau untuk tanah yang terletak didaerah yang jauh dari kedudukan Kantor Pertanahan, dari pemegang hak yang bersangkutan dengan dikuatkan oleh Kepala Desa/Kelurahan; atau salah satu atau para pihak yang akan melakukan perbuatan hukum yang bersangkutan atau salah satu saksi sebagaimana dimaksud dalam Pasal 38 tidak berha atau tidak memenui syarat untuk bertindak demikian; atau Salah satu pihak atau para pihak bertindak atas dasar suatu

24 Mustofa, Ibid, hal. 4-5.

25 Wawancara dengan Afika Hersany selaku Notaris dan Pejabat Pembuat Akta Tanah yang dilaksanakan pada tanggal 15 Mei 2019, pukul 14:00 WIB diruangan Kepala Kantor Notaris dan Pejabat Pembuat Akta Tanah (PPAT) Afika Hersany di Kota Tanjungpinang. 
surat kuasa mutlak ${ }^{26}$ yang pada hakikatnya berisikan perbuatan hukum pemindahan hak.

Beberapa hal yang harus diperhatikan oleh Pejabat Pembuat Akta Tanah sebelum melaksanakan pembuatan Akta diantaranya ${ }^{27}$ Pejabat Pembuat Akta Tanah harus berwenang membuat akta yang berkenaan dengan tempat pembuatan akta; Pejabat Pembuat Akta Tanah harus berwenang membuat akta yang berkenaan orang untuk siapa akta itu dibuat; Pejabat Pembuat Akta Tanah harus berwenang pada waktu akta itu dibuat. Selain dengan hal tersebut PPAT harus melakukan hal-hal tersebut dibawah ini sebelum membuat akta yaitu pada proses melakukan pengecekan baik terhadap identitas maupun Sertifikat atau surat-surat lain yang akan dijadikan/digunkan untuk dasar pembuatan akta; meminta dan menggunakan surat-surat sah khususnya sertifikat dan tanda bukti identitas penghadap untuk dijadikan dasar pembuatan aktanya; meminta bukti pelunasan pajak apabila perbuatan hukum tersebut terkena pajak baik PPh maupun BPHTB; lakukan sesuai dengan kejadiannya baik yang menyangkut tanggal maupun keteranngan penghadap; membuat akta dengan menggunakan blanko resmi yang dikeluarkan oleh Badan Pertanahan Nasional; dan terakhir bacakan dan jeaskan sendiri akta yang anda buat. Persiapan PPAT sebelum membuat akta:Pengecekan sertipikat di Kantor Pertanahan, Melampirkan alat bukti atas hak atas tanah/sertipikat, Melampirkan bukti pelunasan PBB, SSP, SSB, tahun berjalan.

\subsection{Faktor-Faktor yang Menjadi Kendala Eksistensi Peranan Pejabat Pembuat Akta Tanah (PPAT) dalam Perspektif Pendaftaran Tanah (Studi Penelitian di Kecamatan Tanjungpinang Timur Kota Tanjungpinang)}

Dalam bagian ini dijelaskan kembali mengenai ekistensis peranan Pejabat Pembuat Akta Tanah (PPAT) atas keberaan tanah dimana tanah adalah suatu aset negara yang sangat banyak sekali, sumber penghasilan negara juga sebagian besar

26 Wawancara dengan Afika Hersany selaku Notaris dan Pejabat Pembuat Akta Tanah yang dilaksanakan pada tanggal 15 Mei 2019, pukul 14:00 WIB diruangan Kepala Kantor Notaris dan Pejabat Pembuat Akta Tanah (PPAT) Afika Hersany di Kota Tanjungpinang.

27 Wawancara dengan Afika Hersany yang dilaksanakan pada tanggal 15 Mei 2019, pukul 14:00 WIB diruangan Kepala Kantor Notaris dan Pejabat Pembuat Akta Tanah (PPAT) Afika Hersany di Kota Tanjungpinang. 
dari pajak dan salah satu pajak yaitu pajak dari tanah, baik itu pajak bangunan maupun pajak-pajak yang lain misalnya sewa, hak pakai, daln lain sebagainya. ${ }^{28}$

Ketetapan Majelis Permusyawaratan Rakyat yaitu pada Nomor IX/MPR/2001 tentang Pembaruan Agraria dan Pengelolaan Sumber Daya Alam telah mengamatkan bahwa "menghormati dan menjunjung tinggi hak asasi manusia" adalah salah satu prinsip yang wajib ditegakkan oleh (aparat) negara dalam penanganan sengketa agraria. Dengan merujuk pada Tap MPR ini, cara-cara yang ditempuh oleh (aparat) negara itu tentu saja menjadi tindakan yang tragis-ironis. Sekali lagi hal itu pun bisa menunjukkan, betapa kurang baiknya implementasi hukum kita, dan betapa masyarakat yang semestinya dilindungi selalu berada dalam posisi tidak berdaya, selalu dipersalahkan, dan menjadi korban. Malangnya, hampir dalam setiap kasus sengketa tanah, posisi masyarakat selalu lemah atau dilemahkan. Masyarakat sering tidak memiliki dokumen-dokumen legal yang bisa membuktikan kepemilikan tanahnya. Kemampuan masyarakat hanya bersandar pada "kepemilikan historis" dimana tanah yang mereka miliki telah ditempati dan digarap secara turuntemurun. ${ }^{29}$

Pendaftaran hak-hak atas tanah merupakan jaminan dari negara, dan merupakan suatu instrumen penting untuk perlindungan pemilik tanah. Pendaftaran tanah bersifat rechtkadaster yang meliputi kegiatan: 1) pengukuran, pemetaan, dan pembukuan tanah; 2) pendaftaran hak-hak tersebut; 3) pemberian sertifikat hak atas tanah yang berlaku sebagai alat pembuktian yang kuat. ${ }^{30}$

Ditafsirkan sebelum membuat akta seseorang Pejabat Pembuat Akta Tanah perlu meneliti apakah secara administratif sebidang tanah tersebut memenuhi syarat untuk dilakukan perbuatan hukum dihadapan Pejabat Pembuat Akta Tanah dan berada dalam daerah kerjanya. Dalam Peraturan Pemerintah Nomor 24 Tahun 1997 setiap peralihan dan pembebanan hak atas tanah hanya dapat didaftar apabila dibuktikan dengan akta Pejabat Pembuat Akta Tanah.

Berkenaan dengan hal tersebut diatas, prinsip ini maka mengedepankan peranan Pejabat Pembuat Akta Tanah (PPAT) yang sangat penting sebab tanpa adanya

\footnotetext{
${ }_{28}$ Ali Achmad C., Hukum Agraria(pertanahan Indonesia) jilid 1, Prestasi Pustaka, Jakarta, 2004, hal 328.

${ }^{29}$ Effendi Perangin, Hukum Agraria di Indonesia, Raja grafindo Persada, Jakarta, 1989, hal. 102.

${ }^{30}$ Adrian Sutedi, Sertifikat Hak Atas Tanah, Penerbit Sinar Grafika, Jakarta, 2014, hal.59.
} 
Pejabat Pembuat Akta Tanah (PPAT) dapat dirasakan tidak adanya pembuktianpembuktian akta apabila ada suatu permasalahan/sengketa dikemudian hari.

Isdhira Maulid, selaku Kasubsi Pemeliharaan Data Hak Tanah dan Pembinaan Pejabat Pembuat Akta Tanah di Kantor Badan Pertanahan Nasional Kota Tanjungpinang juga menambahkan bahwa dalam pencapaian solusi mencoba meminta jaringan provider optik pada internet tetapi masih belum bisa diakomodir oleh Pusat Jaringan Internet dikarenakan lokasi alamat jauh dari pusat kota, maka hal ini juga berdampak pada proses pendaftaran tanah dimana apabila cuaca kurang bagus, jaringan internet susah didapati, sedangkan pada proses akan terhambat. ${ }^{31}$

Berkenaan informasi mengenai data tanah yang tidak lengkap juga merupakan pemicu kendala yang signifikan. Ketidak lengkapan informasi data tanah ini, juga merupakan faktor kendala yang sifatnya internal, karena semua bahan (row material) untuk penyajian data tanah secara lengkap itu, berawal dari ketidaksiapan dari aparat dan staf pada kantor Pertanahan Kabupaten/Kota setempat, tentu tidak terkecuali dalam konteks yang dibahas dalam penulisan tesis ini pada Kantor Badan Pertanahan Kota Tanjungpinang.

Terkait dengan substansi yang dijelaskan pada bagian diatas, terutama atas ketidak lengkapan informasi data tanah ini, secara bersamaan keadaan ini dapat menimbulkan berbagai dampak yang negatif terkait dengan pemberian pelayanan publik yang berkualitas dibidang Agraria-Pertanahan. Satu diantara dampak yang muncul secara empiris dilapangan, khususnya bagi Kota Tanjungpinang, akan memunculkan perlambatan dalam hal pelaksanaan pembangunan berbagai kegiatan bisnis, baik itu yang bersifat pembangunan infrastrutur, industri jasa dan perdagangan.

Relevan dengan penjelasan yang dijelaskan sebelumnya, atas kurang lengkapnya informasi mengenai data tanah, tentu hal ini akan memunculkan akibat negatif lainnya, satu diantaranya lahir dan tumbuh suburnya spekulan tanah. ${ }^{32}$ Dalam

\footnotetext{
31 Wawancara Penulis dengan Isdhira Maulid, selaku Kasubsi Pemeliharaan Data Hak Tanah dan Pembinaan PPAT Badan Pertanahan Nasional Kota Tanjungpinang, pada tanggal 17 Juni 2019, pukul 10.10 WIB, di Kantor Badan Pertanahan Kota Tanjungpinang

32 H. Mastra Liba, Pikiran, Pandangan, dan Pantauan Mengenai HAM Menuju Good Governance, Rakyat Reformis Menggugat Tegaknya Hukum dan HAM, Yayasan Annisa, Jakarta, 2002, hal.24. Atas hasil verifikasi penulis di lapangan diindikasi masih saja terjadi orang dan/atau pihak tertentu sebagai spekulan tanah dalam konteks pelaksanaan kegiatan pendaftaran tanah tersebut, sehingga dalam pelaksanaannya hal ini sekaligus merupakan kendala/penghambat untuk mempercepat penyelesaian pendafataran tanah dimaksud.
} 
perpektif pelayanan publik yaitu dengan munculnya spekulan tanah itu tentu akan menimbulkan ekonomi biaya tinggi bagi investor yang ingin menanamkan modal investasinya di Kota Tanjungpinang. Jika keadaan dan situasi ini tidak segera dicarikan solusi yang cepat dan konstruktif maka akan memperburuk pemberian pelayanan publik dibidang Agraria-Pertanahan, dan atas keadaan ini sekaligus akan meningkatkan munculnya konflik dan/atau sengketa dibidang pertanahan.

Sejalan dengan penjelasan di atas, khususnya yang berkenaan dengan belum lengkapnya informasi data tanah, untuk kedapannya dan tentu harus dikerjakan dalam waktu yang cepat dan fokus, seharusnya pihak pemerintah dalam hal ini Kementerian Agraria dan Tata Ruang/Badan Pertanahan Nasional Republik Indonesia, harus proaktif untuk melakukan tindakan yang sifatnya revolutif untuk segera membenahi semua perangkat teknologi dan informasi dengan menggunakan spesifikasi perangkat yang berkualitas yang disesuaikan dengan perkembangan teknologi dibidang informasi dan teknologi yang mutakhir/terkini.

Penggunaan Teknolgi Informasi yang berkualitas dan berspesifikasi mutakhir tersebut, menurut pendapat penulis hal itu belumlah cukup, tanpa diikuti dengan sikap kepedulian dari para pegawai dan staf untuk rajin, dan tekun untuk melakukan input dari setiap perkembangan dan/atau perubahan data tanah yang ada. ${ }^{33}$ Dalam hal ini menurut pendapat penulis harus diikuti secara bersamaan dengan peningkatan attitude, sikap dan behaviour dari para staf dan pegawai untuk mempunyai kepedulian yang tinggi, terutama untuk terus melakukan penginputan data secara berkelanjutan terhadap pengumpulan semua data yang telah dilakukan, dan demikian terhadap data yang telah didapat itu harus segera dikerjakan, untuk sekaligus melakukan validasi dan/atau meng up-date dan/atau memperbaharui terhadap segala data perubahan yang berhubungan erat dengan penyajian informasi data tanah dimaksud.

Mengingat sengketa pendaftaran tanah maupun sertifikat tanah sangat banyak dan bervariasi dalam hal jenis sengketa perkaranya, maka kiranya perlu dipikirkan mengenai penyelesaian sengketa tanah, misalnya antara lain, pertama, pembentukan mekanisme dan kelembagaan dalam penyelesaian sengketa pertanahan sebagai

33 Idham, Postulat dan Konstruksi Paradigma Politik Hukum Pendaftaran Tanah Sistematis Lengkap (PTSL) Guna Mewujudkan Negara Berkesejahteraan, Penerbit PT Alumni, Bandung, 2019, hal. 61-63 
upaya mengurangi berbagai gejolak sosial akibat sengketa. Dalam hal ini dapat dibentuk tim penanganan sengketa tanah, baik di tingkat pusat maupun daerah yang bertugas menginventarisasi jenis sengketa dan alternatif penanganannya serta menentukan prioritas kasus yang harus di tangani segera.

Kedua, menetapkan praturan perundang-uandangan mulai dari undang-undang, peraturan pemerintah, keputusan presiden, peraturan daerah, hingga peraturan teknisnya untuk mengatur mekanisme dan cara penyelesaian sengketa tanah, baik melalui proses arbitrase, badan peradilan dan alternatif penyelesaian sengketa pertanahan. Sebelum ada peraturan perundang-undangan yang mengatur penyelesaian sengketa tanah, mekanisme penyelesaian sengketa menuju win-win solution dilakukan melalui mekanisme yang berlaku saat ini. Dalam hal ini dapat diupayakan melalui pengembangan mekanisme penyelesaian sengketa pertanahan di luar badan peradilan (Alternative Dispute Resolution), dan dapat membentuk peradilan pertanahan sebagai bagaian dari system peradilan yang ada dengan tugas khusus menyelesaikan perkara pertanahan secara komprehensif. ${ }^{34}$

Ketiga, mempercepat upaya penyelesaian sengketa Pertanahan melalui: a) koreksi administrasi dengan pembatalan hak atas tanah atau pembatalan sertifikat apabila disebabkan oleh adanya cacat hukum administrasi dalam penerbitan hak atas tanah, dan/atau sertifikat hak atas tanahnya, atau karena adanya putusan pengadilan yang berkekuatan hukum tetap; b) musyawarah, dilakukan apabila para pihak yang bersengketa bersedia untuk saling terbuka dan berdialog; c) koordinasi administrasi/sektor; d) badan peradilan, yang dilakukan terhadap kasus-kasus pertanahan yang pokok sengketanya adalah masalah hak.

Keempat, untuk mengurangi penyelesaian sengketa pertanahan yang berlarutlarut dan menjamin kepastian penegakan hukum, sudah saatnya Pemerintah membentuk Lembaga Peradilan Pertanahan, mengingat perkara pertanahan semakin lama semakin menumpuk di Pengadilan sampai ke Mahkamah Agung.

${ }^{34}$ Adrian Sutedi, Op.cit, hal. 261-262. 
Untuk menanggulangi persoalan tersebut, maka dalam rangka kebijakan pendaftaran tanah ${ }^{35}$ harus dilakukan secara terencana, berkesinambungan, dan komprehensif, melalui sebagai berikut.

1. Mengembangkan system pendaftaran tanah yang efektif dan efisien sebagai upaya memberikan jaminan kepastian hak dan perlindungan hukum bagi pemegang hak.

2. Mewajibkan pendaftaran atas semua jenis hak atas tanah melakukan pencatatan yang berkaitan dengan hak atas tanah, penataan infrastruktur pendaftaran tanah dalam rangka meningkatkan kualitas pelayanan kepada masyarakat, dan penyederhanaan prosedur dan proses pendaftaran tanah,

3. Menyusun dan menetapkan SOP dan Standar Produk Pendaftaran tanah, melakukan percepatan pendaftaran tanah di seluruh wilayah Indonesia, melaksanakan pendaftaran tanah bagi masyarakat berpenghasilan rendah, penataan pembantu pelaksanaan pendaftaran tanah untuk Pejabat Pembuat Akta Tanah dan surveyor berlisensi, penataan program sertifikasi tanah yang ada (Prona, pendaftaran tanah sistematik dan sporadik, Intergrated Area Development, Project, Transmigrasi).

4. Untuk meningkatkan profesionalisme sumber daya manusia di bidang pertanahan, perlu menghidupkan kembali kursus professional setingkat pendidikan D3 agar dapat menghasilkan tenaga yang professional khususnya bidang pendaftaran tanah, pengukuran dan pemetaan yang selama ini keterampilannya tidak diharapkan.

Dengan demikian, apabila kebijakan dapat diterapkan, akan menghasilkan upaya percepatan pensertifikasian tanah dan tertib penggunaan tanah, menciptakan rasa aman dalam pemilikan dan penguasaan tanah, memberikan jaminan kepastian hak atas tanah. Selain itu, kebijakan tersebut akan memberikan pengakuan dan perlindungan semua hak milik atas tanah yang dimilikinya, baik yang sudah maupun

\footnotetext{
35 Darwin Ginting, Op.cit, hal. 193, Pembangunan dan penguasaan tanah harus merupakan pembngunn berkelanjutan yang berwawasan lingkup hidup, yaitu pembangunan secara sadar dan terencana, yang memadukan lingkungan hidup, termasuk sumber daya kedalam proses pembangunan untuk menjamin kemampuan, kesejahteraan dan mutu hidup generasai masa kini dan generasi masa depan. Agar pembangunan dan penguasaan tanah sebagai sumber daya alam sesuai dengan program-program pembangunan berbasiskan kerakyatan sebagaimana diamanahkan dalam Pancasila dan Undang-Undang Dasar Republik Indonesia 1945, maka perlu diselenggarakan pembangunan tanah yang tidak dapat dilepaskan dari pengaturan, penguasaan dan pemilikan tanah.
} 
yang belum terdaftar. Dengan adanya perlindungan tersebut diharapkan setiap pemilik hak atas tanah dapat manfaatkan sumber daya tanah dengan baik dan menciptakan kepastian hukum khususnya hak atas tanah.

\section{PENUTUP}

\subsection{Simpulan}

Pengaturan hukum pendaftaran tanah di Kecamatan Tanjungpinang Timur Kota Tanjungpinang telah terlaksana dengan baik. Berkenaan dengan ditandai pelaksanaan kegiatan pendaftaran tanah dalam bentuk Hak Milik, Hak Guna Bangunan, Hak Pakai, dan Hak Wakaf di Kantor Notaris dan Pejabat Pembuat Akta Tanah (PPAT) Afika Hersany di Kota Tanjungpinang sudah dilakukan sesuai prosedur dalam Peraturan Pemerintah Nomor 37 Tahun 1998 tentang Peraturan Jabatan Pejabat Pembuat Akta Tanah yang mana tugas Pejabat Pembuat Akta Tanah (PPAT) ikut berperan serta membantu masyarakat dalam proses pendaftaran tanah dan dilihat juga pada Kantor Kementerian Agraria dan Tata Ruang/ Badan Pertanahan Nasional Kota Tanjungpinang dilaksanakan dengan prosedur dan ketentuan dalam Peraturan Pemerintah Nomor 24 Tahun 1997 Tentang Pendaftaran Tanah dan Peraturan pelaksanaannya, sehingga dapat meminimalisir kesalahankesalahan yang terjadi sebelumnya dilapangan, karena asas aman dalam pelaksanaan pendaftaran tanah maupun setelah terbitnya sertifikat sebagai produk akhir dalam hak atas tanah.

Implementasi peranan Pejabat Pembuat Akta Tanah (PPAT) dalam perspektif pendaftaran tanah di Kecamatan Tanjungpinang Timur Kota Tanjungpinang, hal ini dilihat pada proses pendaftaran tanah yang dilakukan oleh pihak Pejabat Pembuat Akta Tanah (PPAT) dan pihak Kantor Badan Pertanahan Nasional Kota Tanjungpinang telah terlaksana dengan baik pada langkah dan tindakan konkret yang dilakukakn oleh pihak-pihak Kantor Notaris dan Pejabat Pembuat Akta Tanah (PPAT) Afika Hersany dan pihak Ajudifikasi sesuai dengan prosedur yang diamantkan dalam Peraturan Pemerintah Nomor 24 Tahun 1997 tentang Pendaftaran Tanah.

Faktor yang menjadi kendala/hambatan peranan Pejabat Pembuat Akta Tanah (PPAT) dan pihak Kantor Badan Pertanahan Nasional Kota Tanjungpinang adalah 
kebanyakan kepada masyarakat yang melakukan proses pendaftaran hanya memiliki dokumen sebagian tanpa adanya mengetahui proses syarat-syarat dalam melakukan pendafataran tanah tersebut sehingga pada tahap proses selanjutnya masyarakat harus melengkapi terlebih dahulu syarat-syarat yang akan diproses di Kantor Pejabat Pembuat Akta Tanah (PPAT) dan pihak Kantor Badan Pertanahan Nasional Kota Tanjungpinang, sehingga pada waktu yang dibutuhka untuk pengurusan dokumen dari Kantor Badan Pertanahan Nasional Kota Tanjungpinang cukup lama dan pada biaya pengurusan tidak sedikit dikeluarkan.

\subsection{Saran}

Kantor Notaris dan Pejabat Pembuat Akta Tanah (PPAT) Afika Hersany di Kota Tanjungpinang dan pihak Kantor Badan Pertanahan Nasional di Kota Tanjungpinang, menurut saran penulis harus lebih meningkatkan kinerja tugasnya untuk memberikan informasi kepada masyarakat baik mengenai informasi pendaftaran tanah maupun memberikan informasi tentang syarat-syarat apa saja yang harus dimiliki oleh pemohon apabila akan melakukan permohonan pendaftaran tanah, dilihat pada Peraturan Pemerintah Nomor 24 Tahun 1997 tentang Pendaftaran Tanah. sehingga tidak terjadi hambatan dalam permohonan pendafataran tanah karena syarat-syarat dan bukti yang tidak lengkap dengan memperhatikan UndangUndang tentang Pendaftaran Tanah.

Terkait dengan hal yang dijelaskan diatas, melihat dengan implementasi yang terjadi di masyarakat diharapkan turut aktif dalam usaha untu proses kegiatan pendaftaran tanah agar dapat memberikan jaminan kepastian dan perlindungan hukum kepada pemegang hak atas tanah sebagaimana dalam Undang-Undang Pokok Agraria dan tujuan pembangunan nasionnal serta demi terwujudnya pemerataan bidang-bidang tanah diseluruh wilayah Indonesia pada umumnya dan Kota Tanjungpinang pada khususnya.

Langkah penting selanjutnya melihat pada faktor kendala dan solusi maka perlu untuk diintesifkan dalam proses pengawasan dan mekanisme kerja agar pemanfaatan dan penggunaan tanah serta peningkatan sumber daya manusia dalam lingkungan Kantor Pejabat Pembuat Akta Tanah (PPAT) dan pihak Kantor Badan 
Pertanahan Nasional Kota Tanjungpinang terlepas dari hambatan-hambatan didalam pelaksanaan pendaftaran tanah yang dapat diminimalisir.

\section{DAFTAR PUSTAKA}

\section{A. Buku-Buku}

Adrian Sutedi, Sertifikat Hak Atas Tanah, Penerbit Sinar Grafika, Jakarta, 2014

Ali Achmad C, Hukum Agraria(pertanahan Indonesia) jilid 1, Prestasi Pustaka, Jakarta, 2004.

A.P.Parlindungan, Pedoman Pelaksanaan Undang-Undang Pokok Agraria dan Tata Cara Pejabat Pembuat Akta Tanah, CV. Mandar Maju, Bandung, 1991.

Boedi Harsono,. Hukum Agraria Indonesia: Sejarah Pembentukan UUPA Isi dan Pelaksanaanya, Ed. Revisi. Cet.8. Djambatan, 2003. Jakarta.

Bernhard Limbong, Konflik Pertanahan, Margaretha Pustaka, Jakarta, 2012.

Darwin Ginting, Hukum Kepemilikan Hak Atas Tanah Bidang Agraria Bisnis Hak Menguasai Negara dalam Sistem Hukum Pertanahan Indonesia, Penerbit Ghalia Indonesia, Jakarta, 2015.

Effendi Bahtiar, Kumpulan Tulisan Tentang Hukum Tanah, Alumni, Bandung, 1993.

Effendi Perangin, Hukum Agraria di Indonesia, Raja Grafindo Persada, Jakarta, 1994.

Habib Adjie, Meneropong Khazanah Notaris dan PPAT di Indonesia (Kumpulan Tulisan tentang Notaris dan PPAT), Citra Aditya Bakti, Bandung, 2009.

H. Mastra Liba, Pikiran, Pandangan, dan Pantauan Mengenai HAM Menuju Good Governance, Rakyat Reformis Menggugat Tegaknya Hukum dan HAM, Yayasan Annisa, Jakarta, 2002.

Idham, Analisis Kritis Pendaftaran Tanah Hak Ulayat Milik Masyarakat Adat Untuk Meneguhkan Kepastian Hukum dan Peningkatan Ekonomi Kerakyatan, Penerbit PT Alumni, Bandung, 2014.

Idham, Postulat dan Konstruksi Paradigma Politik Hukum Pendaftaran Tanah Sistematis Lengkap (PTSL) Guna Mewujudkan Negara Berkesejahteraan, Penerbit PT Alumni, Bandung, 2019.

Idham, Paradigma Politik Hukum Pendaftaran Tanah dan Konsolidasi Tanah dalam Perspektif Free Trade Zone (FTZ) di Kota Batam, Penerbit Alumni, Bandung, 2016.

Irwan Soerodjo, Kepastian Hukum Hak Atas Tanah di Indonesia, Arkola, Surabaya, 2003.

Salim HS dan Erlies Septiana Nurbani, Penerapan Teori Hukum Pada Tesis dan Disertasi, Raja Grafindo Persada, Jakarta, 2014. 
Soedharyo Soimin, Status Hak dan Pembebasan Tanah, Edisi Kedua, Sinar Grafik, Jakarta, 2004 .

Soerjono Soekanto dan Sri Mamudji, 2010, Penelitian Hukum Normatif, PT. Raja Grafindo Persada, Jakarta.

Mustofa, Tuntunan Pembuatan Akta-Akta PPAT, Penerbit Karya Media, Yogyakarta, 2014.

Udin Narsudin, Buku Pembekalan PPAT, Penerbit Pengurus Pusat Ikatan Pejabat Peembuat Akta Tanah, 2015.

Waskito dan Hadi Arnowo, Pertanahan Agraria dan Tata Ruang, Penerbit Prenadamedia Group, Jakarta, 2018

Zainudin Ali, Metode Penelitian Hukum, Sinar Grafka, Jakarta, 2009

\section{B. Peraturan Perundang-Undangan}

Kitab Undang-Undang Hukum Perdata (KUHPerdata)

Undang-Undang Dasar Negara Republik Indonesia Tahun 1945

Peraturan Pemerintah Nomor 37 Tahun 1998 tentang Peraturan Jabatan Pejabat Pembuat Akta Tana

Peraturan Pemerintah Nomor 24 Tahun 1997 tentang Pendaftaran Tanah. 